\title{
PELATIHAN KEUANGAN SEDERHANA BAGI IBU PKK DI DESA SUKAJAYA LEMPASING KABUPATEN PESAWARAN
}

\author{
Hardini Ariningrum ${ }^{1}$, Apip Alansori ${ }^{2}$, Rahyono ${ }^{3}$ \\ ${ }^{12,3)}$ Program Studi Akuntansi, Fakultas Ekonomi, Universitas Malahayati \\ e-mail: hardini.ariningrum@gmail.com
}

\begin{abstract}
Abstrak
Pengelolaan keuangan keluarga terkait dengan mengatur alokasi keuangan keluarga untuk memenuhi memenuhi kebutuhan saat ini, kebutuhan di masa depan dan kebutuhan yang tidak terduga yang mempengaruhi kondisi keuangan keluarga. Masalah yang dihadapi ibu rumah tangga adalah mereka kurang bisa merencanakan dan mengelola keuangan, mereka menggunakan keuangannya secara tradisional. Tidak ada penulisan bagaimana uang masuk dan uang keluar sehingga setiap akhir bulan uang tidak terkontrol penggunaannya. Tujuan kegiatan pengabdian kepada masyarakat ini adalah untuk memberikan pelatihan tentang pengelolaan keuangan keluarga secara sedrhana kepada ibu PKK agar bisa mengelola keuangan keluarga supaya terhindar dari hutang akibat terlalu banyaknya pengeuaran dalam menjalankan aktivitas sehari-hari. Manfaat dari kegiatan ini bagi mitra pengabdian adalah memberikan pengetahuan tentang cara merencanakan pengeluaran keuangan keluarga, pelaksanaan manajemen keuangan keluarga dan penilaian/ pengawasan keuangan keluarga dan menciptakan kesejahteraan. Metode yang digunakan dalam melaksanakan kegiatan ini adalah membuat rencana kegiatan pengabdian pada masyarakat yang meliputi tahap persiapan, perencanaan dan evaluasi. Diharapkan dengan adanya kegiatan pengabdian pada masyarakat ini bisa membatu para ibu-ibu PKK dalam mengelola keuangan keluarga supaya bisa memahami seberapa pentingnya pengendalian terhadap keuangan supaya terhidar dari hutang dan bisa meningkatkan pendapatan dengan cara mengurangi pengeluaran yang kurang diperlukan.
\end{abstract}

Kata Kunci: Keuangan Sederhana, Perencanaan Keuangan, Ibu PKK.

\begin{abstract}
Family financial management is related to managing family financial allocations to meet current needs, future needs and unforeseen needs that affect the family's financial condition. The problem housewives face is that they cannot plan and manage finances, they use their finances traditionally. There is no writing on how money comes in and money goes out so that at the end of each month the use of money is not controlled. The purpose of this community service activity is to provide training on simple family financial management to PKK mothers so that they can manage family finances in order to avoid debt due to too much expenditure in carrying out daily activities. The benefit of this activity for community service partners is to provide knowledge about how to plan family financial expenses, implement family financial management and assess / monitor family finances and create welfare. The method used in carrying out this activity is to plan community service activities which include preparation, planning and evaluation stages. It is hoped that this community service activity can help PKK mothers in managing family finances so that they can understand how important financial control is so that they avoid debt and can increase income by reducing unnecessary expenses.
\end{abstract}

Keywords: Simple Finance, Financial Planning, Mrs. PKK.

\section{PENDAHULUAN}

Upaya yang dapat dilakukan untuk merubah perlakuan masyarakat Indonesia yang konsumtif adalah melalui pengelolaan keuangan rumah tangga. Dengan menyadarkan pengelolaan keuangan sederhana sesuai dengan prinsip dalam manajemen yang efisien dan efektif diharapkan akan memberikan sumbangan terhadap perubahan pola hidup konsumtif kearah pengelolaan keuangan yang lebih baik, dengan harapan tidak menghabiskan seluruh pendapatan yang diterima dan 
menyisihkan pendapatan untuk ditabung dan digunakan sesuai dengan kebutuhan. Keuangan adalah masalah umum yang dihadapi oleh setiap orang. Seringkali timbul permasalahan bagaimana cara mengatur keuangan bukan terletak pada penghasilan yang kurang namun adanya kebiasaan yang salah dalam mengelola keuangan karena seringkali salah memprioritaskan pengeluarannya.

Mengelola keuangan keluarga nampaknya begitu sederhana. Namun dalam praktiknya banyak sekali orang yang tidak mampu mengelolanya dengan baik karena alokasi anggaran dan belanja keluarga (rumah tangga) yang sederhana jika tidak dikelola dengan baik maka melahirkan keluarga yang gali lobang tutup lobang. Hidup selalu kurang dan kurang lagi, meskipun nominal pendapatan telah mengalami peningkatan (Hariani et al., 2019).

Pengelolaan keuangan keluarga terkait dengan mengatur alokasi keuangan keluarga untuk memenuhi memenuhi kebutuhan saat ini, kebutuhan di masa depan dan kebutuhan yang tidak terduga. Kebutuhan saat ini terdiri atas pengeluaran-pengeluaran yang dikeluarkan saat ini, antara lain seperti pengeluaran untuk biaya dapur, biaya cicilan motor, biaya pulsa telepon genggam dan lain-lain. Kebutuhan di masa depan terdiri atas pengeluaran-pengeluaran dikeluarkan di masa mendatang, antara lain seperti pengeluaran untuk biaya pendidikan anak hingga tamat sekolah, biaya naik haji biaya pernikahan anak. Sedangkan kebutuhan tidak terduga terkait dengan pengeluaran yang tidak terduga sebelumnya misalnya biaya pengobatan. Dengan demikian, kondisi ini akan berpengaruh terhadap kehidupan keluarga, dan ujung-ujungnya keluarga menjadi tidak sejahtera (Budiantoro et al., 2019)

Masalah yang dihadapi ibu rumah tangga adalah mereka kurang bisa merencanakan dan mengelola keuangan, mereka menggunakan keuangannya secara tradisional. Tidak ada penulisan bagaimana uang masuk dan uang keluar sehingga setiap akhir bulan uang tidak terkontrol penggunaannya. Masalah yang dihadapi ibu-ibu tersebut mendorong tim pengabdian untuk membantu merencanakan keuangan dan melakukan pembukuan sederhana sebagai sarana untuk meningkatkan terah hidup dan perekonomian keluarga (Marsudi \& Robbie, 2020).

Pengelolaan keuangan sering disebut perencanaan keuangan. Perencanaan keuangan adalah upaya yang untuk mengalokasikan pendapatan dan pengeluaran sebuah keluarga secara baik dan benar untuk mewujudkan tujuan keuangan keluarga (Ridwan, 2015). Salah satu tujuan pengeloaan keuangan adalah agar siklus keuangan keluarga dalam berjalan sesuai dengan rencana dan tujuan keuangan keluarga atau mengatur agar terjadi keseimbangan antara pendapatan dan pengeluaran keluarga. Dengan demikian, apabila perencanaan keuangan tidak diperhatikan, yang akan terjadi adalah ketidak keseimbangan antara pendapatan dan pengeluaran misalnya jumlah pengeluran menjadi lebih besar dibanding dengan pendapatan. Pengeluaran yang besar tersebut, biasanya bersumber dari hutang. Hal ini yang dapat memicu munculnya masalah yang besar bagi keluarga (Cahyani et al., 2019).

Kelompok PKK adalah kumpulan ibu-ibu yang sehari-harinya bekerja sebagai ibu rumah tangga. Dan disisi lain, mereka mengisi waktu dengan beberapa kegiatan sosial seperti arisan, pengajian atau mengikuti kegiatan program PKK (Pemberdayaan Kesejahteraan Keluarga) yang diadakan di lingkungan masyarakat.

Kegiatan Pengabdian Kepada Masyarakat yang dilakukan dalam bentuk pelatihan tentang pengelolaan keuangan sederhana kepada ibu-ibu anggota PKK di Desa Sukajaya Lempasing Kabupaten Pesawaran sebagai mitra pengabdian. Target kegiatan ini adalah menghasilkan jasa yang bisa berupa ilmu pengetahuan tentang cara mengelola keuangan keluarga, yang meliputi ilmu pengetahuan tentang perencanaan pengeluaran keuangan keluarga, ilmu pengetahuan tentang pelaksanaan manajemen keuangan keluarga, dan ilmu pengetahuan tentang penilaian/ pengawasan keuangan keluarga.

Tujuan kegiatan pengabdian kepada masyarakat ini adalah untuk memberikan pelatihan tentang pengelolaan keuangan keluarga secara sedrhana kepada ibu PKK agar bisa mengelola keuangan keluarga supaya terhindar dari hutang akibat terlalu banyaknya pengeuaran dalam menjalankan aktivitas sehari-hari. Manfaat dari kegiatan ini bagi mitra pengabdian adalah memberikan pengetahuan tentang cara merencanakan pengeluaran keuangan keluarga, pelaksanaan manajemen keuangan keluarga dan penilaian/ pengawasan keuangan keluarga dan menciptakan kesejahteraan.

Berdasarkan gambaran diatas, maka dapat diambil beberapa permasalahan yang ada pada masyarakat dalam hal ini ibu rumah tangga adalah keterampilan yang dimiliki masih perlu 
ditingkatkan untuk menciptakan kesadaran mengenai pentingnya perencanaan keuangan dan pembuatan pembukuan sederhana. Masih rendahnya pengetahuan dan praktek membuat perencanaan keuangan dan pembukuan sederhana bagi ibu rumah tangga untuk meningkatkan perekonomian dan keuangan keluarga.

Setelah mengikuti pelatihan ini, semua peserta akan memiliki kesadaran, pola fikir dan pola sikap hidup yang konstruktif terutama dalam hal pemanfaatan pendapatan keluarga, serta mampu menggunakannya sesuai alokasi dan peruntukan berdasarkan skala prioritas keluarga. Dimana antara lain sebagai ibu rumah tangga yang tidak bekerja, ibu rumah tangga yang bekerja, dan ibu rumah tangga yang memiliki bisnis sendiri dengan latar belakang pendidikan rata-rata sampai sekolah menengah, serta latar belakang ekonomi keluarga menengah ke bawah.

\section{METODE}

Metode yang digunakan dalam melaksanakan kegiatan ini adalah dengan melakukan diskusi dan koordinasi terlebih dahulu kepada Kepala Desa dan ibu-ibu PKK Desa Sukajaya yang termasuk didalamnya terkait dengan pelaksanaan dan sasaran masyarakat wilayah setempat. Pelaksanaan pada awalnya peserta pelatihan diberikan pemahaman tentang manfaat dan pentingnya perancanaan keuangan keluarga.

Peserta pelatihan berikutnya diberikan penjelasan tentang cara penyusunan laporan keuangan sederhana, kemudian peserta dilatih untuk membuat perencanaan keuangan keluarga dengan template atau lembar kerja yang sudah disediakan, sehingga mempermudah dalam pembuatan dan pada akhirnya mampu menghasilkan perencanaan keuangan keluarga yang matang dan baik. Rancangan kegiatan pengabdian masyarakat menjadi tiga tahap yaitu:

Table 1.

Rencana Kegiatan Pengabdian pada Masyarakat

\begin{tabular}{|c|c|c|}
\hline NO & TAHAPAN KEGIATAN & URAIAN TUGAS \\
\hline 1 & Persiapan & $\begin{array}{l}\text { a. Persiapan kelengkapan administrasi ; } \\
\text { surat menyurat, surat izin, bahan, materi. } \\
\text { b. Persiapan media dan fasilitas penunjang } \\
\text { c. Persiapan undangan peserta, power } \\
\text { point, penyusunan template, modul } \\
\text { materi. } \\
\text { 1. Persiapan pengurusan surat tugas, } \\
\text { surat izin melakukan kegiatan dan } \\
\text { materi. } \\
\text { 2. LCD Projector, Laptop, Template } \\
\text { (Lembar Kerja). } \\
\text { 3. Lembar Undangan peserta } \\
\text { d. Persiapan panitia pengabdian } \\
\text { masyarakat tang } \\
\text { 1. Pembagian tugas dan tangung } \\
\text { jawab. } \\
\text { e. Metode: } \\
\text { 1. Studi Literatur } \\
\text { 2. Diskusi } \\
\text { f. Penetapan Lokasi Pelatihan, pelatihan } \\
\text { dilakukan di Aula Desa Sukajaya } \\
\text { Lempasing Kabupaten Pesawaran. }\end{array}$ \\
\hline 2 & & $\begin{array}{l}\text { Penyampaian materi: } \\
\text { a. Pembukaan } \\
\text { b. Penyampaian materi } \\
\text { 1. Penjelasan pentingnya melakukan } \\
\text { pencatatan dan pembukuan. } \\
\text { 2. Pengertian dasar perencanaan }\end{array}$ \\
\hline
\end{tabular}




\begin{tabular}{|c|c|c|}
\hline & Pelaksanaan & $\begin{array}{l}\text { keuangan. } \\
\text { 3. Perencanaan keuangan keluarga. } \\
\text { 4. Proses dan tahapan pencatatan } \\
\text { perencanaan keuangan rumah } \\
\text { tangga. } \\
\text { 5. Praktek pembuatan perencanaan } \\
\text { pencatatan keuangan keluarga. } \\
\text { 6. Pengukuran dan koreksi dalam } \\
\text { setiap perencanaan yang dibuat. } \\
\text { c. Metode: } \\
\text { 1. Diskusi, Ceramah, Workshop dan } \\
\text { Tanya jawab. }\end{array}$ \\
\hline 3 & Evaluasi & $\begin{array}{l}\text { a. Evaluasi hasil pelatihan (resume lembar } \\
\text { kerja yang sudah dibuat peserta). } \\
\text { b. Diskusi dan Tanya jawab. }\end{array}$ \\
\hline
\end{tabular}

\section{HASIL DAN PEMBAHASAN}

Kegiatan pengabdian masyarakat ini diselenggarakan oleh Universitas Malahayati dan bekerjasama dengan Pemerintah desa Sukajaya Lempasing Pesawaran. Peserta dalam kegiatan ini adalah ibu-ibu PKK yang berada dilingkungan desa sukajaya dan mewakili dari setiap RT. Pelatihan dilaksanakan selama 1 hari pada tanggal 20 Februari 2020 yang bertempat diaula desa sukajaya. Setelah pelatihan dilakukan, pendampingan tetap diberikan selama 1 minggu. Metode pelaksanaan yang dilakukan yang pertama adalah tim berkoordinasi dengan pihak Universitas dan pihak desa untuk melakukan pengabdian dengan materi yang disampaikan sesuai keadaan dan kebutuhan masyarakat sekitar, yang berikutnya dibuatkan berkas administratif dalam pembuatan surat izin pelaksanaan kegiatan pengabdian yang ditujukan kepada pihak desa. Berikutnya tim melakukan pembagian undangan dan sosialisasi terlebih dahulu kepada calon peserta dan memberikan modul kepada peserta berikut beberapa penjelasan terkait pelatihan yang akan diadakan sesuai jadwal yang telah ditentukan.

Peserta yang menghadiri kegiatan pelatihan tersebut merupakan ibu ibu yang sudah berkeluarga dengan latar belakang yang beragam namun yang mendominasi kebanyakan ibu rumah tangga. Sehingga ketika pelaksanaan pelatihan seluruh peserta dapat mengikuti acara sampai dengan selesai. Narasumber dalam pelatihan ini adalah Hardini Arinigrum, S.E.,M.Ak, Apip Alansori, SE.,M.Ak.,CAPM, dan Rahyono, S.Sos.,M.M yang dibantu oleh beberapa mahasiswa dalam penyampaian materi berikut dengan pembimingan pelatihan.

Kegiatan Pengabdian ini akan dievaluasi melalui pemberian kertas kerja dengan cara belajar dalam menulis suatu transaksi secara sederhana, untuk mengetahui peningkatan pengetahuan tentang laporan keuangan. Pelaksanaan kegiatan Pengabdian pada Masyarakat ini dilakukan dengan menggunakan metode ceramah, tutorial, dan diskusi. Adapun tahapan pelaksanaan kegiatan pengabdian ini adalah sebagai berikut:

1. Langkah 1 (Metode Ceramah)

Peserta diberikan wawasan mengenai pentingnya laporan keuangan dalam memenuhi kebutuhan keluarga. Langkah pertama diselenggarakan melalui metode ceramah selama 20 menit.

2. Langkah 2 (Metode Tutorial)

Peserta pelatihan diberikan materi tentang penyusunan laporan keuangan, meliputi: laporan laba rugi, laporan perubahan modal, neraca serta laporan arus kas. Materi ini disampaikan dalam bentuk tutorial disertai dengan latihan/studi kasus. Langkah kedua diselenggarakan selama 1 jam.

3. Langkah 3 (Metode Diskusi)

Peserta pelatihan diberikan kesempatan untuk mendiskusikan permasalahan yang berkaitan dengan usaha yang sudah mereka jalani ataupun hal-hal yang ingin mereka tanyakan untuk memulai usaha. Langkah ketiga diselenggarakan selama 1 jam. 
Setelah dilakukan penyampaian materi, peserta diarahkan untuk membuat laporan keuangan sederhana, hasilnya sebagian besar peserta telah mampu membuat laporan keuangan sederhana seperti laporan laba rugi, perubahan ekuitas dan arus kas. Namun untuk neraca, diketahui bahwa sebagian peserta cukup mengalami kesulitan, hal ini mayoritas disebabkan oleh kurangnya ketelitian peserta sehingga umumnya laporan neraca yang dibuat tidak seimbang (unbalanced). Namun secara umum dapat disimpulkan bahwa Peserta telah mampu baik untuk membuat laporan keuangan sederhana baik secara personal maupun secara berkelompok (Seto et al., 2017).

Pelaksanaan kegiatan pengabdian kepada masyarakat dirasa memiliki menfaat yang sangat berarti. Dilihat dari antusias masyarakat terlebih ibu PKK yang terlibat dalam acara pelatihan tersebut. pelatihan ini sangat berguna dalam memberikan pemahaman dan ilmu pengetahuan yang pada akhirnya dapat diimplementasikan dirumah tangga dalam pengelolaan keuangan dan pembagian pos-pos keuangan dari yang penting bersifat pemenuhan kebutuhan hingga mengantisipasi dan mengklasifikasi pemenuhan yang bersifat keinginan. Tata kelola keuangan yang baik akan sangat membantu kondisi keuangan di rumah tangga yang pada akhirnya dapat membantu menciptakan dan mendorong keluarga untuk menabung dan melakukan investasi dengan apa yang dimiliki dan dialokasikan (Mulyanti \& Nurdin, 2018). Manfaat yang dirasakan ini sebelumya disampaikan oleh ketua PKK di desa sukajaya yang menyampaikan bahwa pelatihan yang diberikan tentunya sangat bermanfaat dalam memberikan pemahaman perencanaan keuangan bagi rumah tangga. Khususnya ibu-ibu PKK yang berada dilingkungan desa sukajaya. Antusiasme peserta juga dapat diliihat dari banyaknya pertanyaan dan diskusi yang dilakukan semua pertanyaan dan diskusi yang dilakukan dapat dijelaskan dan disampaikan dengan baik dengan harapan mampu mempermudah pemahaman materi.

Adapun hasil kegiatan pengabdian masyarakat ini adalah ibu-ibu dapat memahami pentingnya perencanaan keuangan bagi keluarga. Disamping itu ibu-ibu dapat mempraktekkan mengenai perencanaan keuangan bagi keluarga melaui pembukuan sederhana.

Pelatihan yang sudah berjalan dengan lancar akan mewujudkan suatu administrasi yang baik. Ada perencanaan kegiatan, pelaksanaan dan monitoring serta komunikasi mengenai evaluasi hasil kegiatan. Hal yang penting adalah kegiatan tersebut harus terdokumentasi dengan baik disertai dengan adanya berita acara pada setiap kegiatan. Tetapi perlu dilakukan pendampingan lanjutan untuk menjadikan budaya yang baik khususnya bagi ibu rumah tangga untuk konsisten dalam mengelola keuangan bagi keluarga.

\section{SIMPULAN}

Berdasarkan hasil dan pembahasan yang sudah disampaikan pada pelaksanaan pengabdian masyarakat mengenai pelatihan perencanaan keuangan keluarga sederhana yang ditujukan bagi ibu ibu PKK pemerintah daerah desa Cimenyan yang telah diuraikan sebelumnya, dapat diambil kesimpulan sebagai berikut:

1. Meningkatnya pemahaman keuangan keluarga sederhana setelah mengikuti pelatihan, peserta mampu membuat perencanaan keuangan yang bermanfaat dalam mengelola keuangan rumah tangga.

2. Mampu meningkatkan kesadaran peserta pelatihan tentang pentingnya perencanaan keuangan keluarga setelah mengikuti pelatihan.

3. Meningkatnya motivasi peserta pelatihan untuk melakukan pembuatan anggaran untuk menabung dan berinvestasi dalam mengelola keuangan.

4. Peserta pelatihan mampu menyusun dan simulasi pengelolaan keuangan dalam proses peyusunan perencanaan keuangan dari total penghasilan yang dimiliki dan alokasi anggaran yang harus dilakukan untuk mempermudah keluarga dalam mengelola keuangan.

5. Pelatihan lapran keuangan sederhana pada ibu PKK telah berjalan dengan baik dan lancar serta dapat meningkatkan penyusunan dan pengelolaan keuangan sehingga dapat diterapkan praktis dalam keluarga.

\section{SARAN}

Kegiatan pengabdian pada masyarakat tentang laporan keunagan sederhana dilakukan dengan waktu yang singkat, karena untuk memahami laporan keuangan harus memiliki waktu yang cukup agar para ibu-ibu bisa memahami sepenuh ya tentang laporan keuangan. Namun ternyata telah 
memberikan dampak yang luas terhadap motivasi ibu PKK. Kedepan sangat diharapkan agar perguruan tinggi bisa bekerjasama dengan mitra dari dunia usaha agar dapat melaksanakan kegiatan pengabdian pada masyarakat ini secara lebih lama dan menjangkau kelompok PKK lebih banyak lagi.

\section{UCAPAN TERIMA KASIH}

Ucapan Terima kasih tak terhingga kami sampaikan kepada Tim Pengabdian pada masyarakat Universita Malahayati Bandar Lampung, Kepala Desa Sukajaya Lempasing Pesawaran, kelompok PKK desa Sukajaya Lempasing Pesawaran, dan semua kalangan masyarakat yang sudah memfasilitasi dan memberi dukungan penuh kepada kami dalam melaksanakan kegiatan Pengabdian kepada Masyarakat (PkM) ini.

\section{DAFTAR PUSTAKA}

Budiantoro, H., Sari, I., Hukama, L. D., Zain, E., \& Simon, Z. Z. (2019). Pelatihan Pengelolaan Keuangan Bagi Ibu-Ibu Rumah Tangga Dan Kader Pkk Rt 16 Rw 04 Kelurahan Cempaka Putih Timur. SELAPARANG Jurnal Pengabdian Masyarakat Berkemajuan, 2(2), 24. https://doi.org/10.31764/jpmb.v2i2.882

Cahyani, P. D., Maharani, B. D., Tria, L., Hutami, H., \& Pendahuluan, I. (2019). Motivasi Wirausaha dan Pelatihan Penganggaran serta Pembukuan pada Ibu-ibu PKK Pedukuhan Wonocatur , Banguntapan Bantul. Jurnal Akses Pengabdian Indonesia (JAPI), 4(2), 87-91. https://doi.org/10.33366/japi.v4i2.1584

Handbook, T., \& Planning, F. F. (n.d.) (2015). Mengelola Keuangan Keluarga Secara Islami.

Hariani, S., Yustikasari, Y., Akbar, T., Ekonomi, F., \& Mercubuana, U. (2019). Pelatihan Pengelolaan Keuangan Rumah Tangga Bagi Ibu-Ibu Rumah Tangga Di Cengkareng Barat Wilayah Jakarta Barat Pelatihan Pengelolaan Keuangan Rumah Tangga Bagi Ibu-Ibu Rumah Tangga Di Cengkareng Barat Wilayah Jakarta Barat. Bedaya: Jurnal Pendidikan Dan Pengabdian Kepada Masyarakat, $1(1), \quad$ 15-22. https://ejournal.imperiuminstitute.org/index.php/BERDAYA

Marsudi, M., \& Robbie, R. I. (2020). Pelatihan Perencanaan Keuangan Dan Pembukuan Sederhana Pada Ibu Rumah Tangga Di Desa Pendem Kecamatan Junrejo Kota Batu. Qardhul Hasan: Media Pengabdian Kepada Masyarakat, 6(1), 22. https://doi.org/10.30997/qh.v6i1.1951

Mulyanti, D., \& Nurdin, S. (2018). Pelatihan Perencanaan Keuangan Keluarga Bagi Ibu Ibu PKK Desa Cimenyan Kabupaten Bandung. 1(2), 259-267.

Seto, A. A., Andriyani, I., \& Putra, D. P. (2017). Pelatihan Pembuatan Laporan Keuangan Sederhana Pada Ibu-Ibu Pkk Kecamatan Sako Palembang. Jurnal Abdimas Mandiri, 1(2), 7883. 